\title{
„KRAKOWSKIE” WOLUMINY Z DAWNEJ BIBLIOTEKI BERNARDYNÓW NA KARCZÓWCE POD KIELCAMI
}

STRESZCZENIE: Artykuł prezentuje ustalenia dotyczące „krakowskiej” proweniencji niektórych woluminów z dawnej biblioteki bernardynów na Karczówce, które obecnie znajdują się w zasobie Biblioteki Wyższego Seminarium Duchownego w Kielcach. Konwent Braci Mniejszych Obserwantów posiadał od początku swojego funkcjonowania (lata 30. XVII w.) wiele starodruków (zapewne też rękopisów liturgicznych) przekazanych przez władze zakonne prowincji, jak również krakowskich kanoników i profesorów uniwersyteckich. Ich identyfikację umożliwiły zachowane proweniencje oraz inne notki, m.in. wskazujące na konkretne przeznaczenie.

SLOWA KLUCZOWE: bernardyni, Karczówka, księgozbiór, XVII w.

\section{„CRACOW” VOLUMES FROM THE OLD LIBRARY OF THE BERNARDINES IN KARCZÓWKA NEAR KIELCE}

\begin{abstract}
The article presents the conclusions concerning the "Cracow" provenance of some volumes originating from the former Bernardines library in Karczów$\mathrm{ka}$, which are currently stored in the Major Seminary in Kielce. Since the beginning of its functioning (the begining of the 1630s), the convent of the Friars Minor, the Observants was in the posession of the old prints (including liturgical manuscripts probably) donated by the province monastery authorities, Cracow canons as well as university professors. The identification of the specific items of the collection has been possible due to preserved provenance entries as well as other entries indicating the particular item's purpose.
\end{abstract}

KEYWORDS: Bernardines, Karczówka, library, the $17^{\text {th }}$ century.

Translated by Piotr Kardyś

„Nasza Przeszłość” t. 134: 2020, s. 67-94. 
W zrekonstruowanym księgozbiorze oo. bernardynów z Karczówki ${ }^{1}$ udało się zlokalizować przynajmniej kilkanaście starodruków, które trafiły do biblioteki konwentu na Górze św. Karola Boromeusza ${ }^{2}$ od krakowskich duchownych, bądź dotarły bezpośrednio do nowo założonej placówki z klasztoru macierzystego w Krakowie. Wskazują na to bezpośrednio zachowane wpisy proweniencyjne, a w przypadku pewnej ich liczby także pośrednio analiza ich treści (pod kątem przeznaczenia miejsca i wspólnoty), a także autorstwo i zawartość poszczególnych starodruków - jeśli weźmie się pod uwagę formację intelektualną Ordo Fratrum Minorum Sancti Francisci de Observantia oraz potrzeby organizacyjne nowej wspólnoty.

Zanim przejdziemy do omówienia tych interesujących pod wieloma względami przykładów migracji ksiąg w ramach małopolskiej prowincji bernardynów w okresie staropolskim należy pokrótce przypomnieć najważniejsze fakty $\mathrm{z}$ historii ojców i braci $\mathrm{z}$ Karczówki ${ }^{3}$, a także dzieje zgromadzonego przez nich księgozbioru.

Bernardyni znaleźli się na Karczówce w wyniku szeregu działań i splotu korzystnych dla nich faktów, których obecnie nie możemy w pełni wyjaśnić. Początki założenia fundacji na Karczówce wiążą się z działalnością bp. krakowskiego Marcina Szyszkowskiego, będącego właścicielem Kielc i okolicznych terenów, który pragnąc podziękować Bogu za uchronienie Kielc od epidemii, ufundował w 1624 r. kościół

\footnotetext{
${ }^{1} \mathrm{P} . \mathrm{K}$ a r d y ś, Patrum Bernardinorum Conventus Sancti Caroli Kielcijs ad Bibliothecam. Biblioteka oo. bernardynów z Karczówki od założenia konwentu do XIX wieku, [w:] Dzieje Karczówki w Kielcach (pod Kielcami) w latach 1624-2024, t. 6, Biblioteka bernardynów na Karczówce od 1632 roku do kasaty klasztoru w 1864 roku, red. J. M i c h t a, Kielce 2019, s. 13-270.

2 Takie odmiejscowo-patronackie określenie znajduje się w kilku starodrukach należących przed kasatą Karczówki do jej biblioteki, zob. P. K a r d y ś, Patrum Bernardinorum, s. 63: „Pro loco Montis S. Caroli Boromaei”, „Pro Libraria Conventus patrum Sancti Caroli in Monte”, „Pro loco Montis Sancti Caroli Patrum Bernardinorum”.

${ }^{3}$ Najważniejsze prace dotyczące Karczówki, zob.: J. Z d a n o w s k i, Karczówka pod Kielcami, Kielce 1928; W. F. M u r a w i e c, Kielce, [w:] Klasztory bernardyńskie $w$ Polsce $w$ jej granicach historycznych, red. H. E. W y c z a w s k i, Kalwaria Zebrzydowska, 1985, s, 134; Karczówka. Historia - literatura - architektura - przyroda, red. J. L. O 1 s z e w s k i, Kielce 1995; M. P i e n i ą ż e k - S a m e k, Kościól i klasztor na Karczówce $w$ dobie nowożytnej; architektura $i$ wyposażenie, „Studia MuzealnoHistoryczne" t. 4, 2012, s. 11-31; C. J a s t r z ę b s k i, Kasata klasztoru Bernardynów na Karczówce w 1864 roku, tamże, s. 33-43; Dzieje Karczówki w Kielcach w latach 1624 2024, t. 1: Poczatki fundacji, insygnia, fundator, red. J. M i c h t a, Kielce 2016, passim.
} 
pod wezwaniem św. Karola Boromeusza ${ }^{4}$. Warto w tym miejscu podkreślić, że bp ufundował kościół, a nie klasztor. Jest to o tyle ważne, że w świadomości większości historyków Kościoła i też w licznych opracowaniach, zwłaszcza starszych, w których wymieniana była Karczówka, fundacja kościoła przez bp. M. Szyszkowskiego była utożsamiana z fundacją klasztoru bernardynów ${ }^{5}$. Przykładem narosłych wokół tego faktu nieporozumień, budowanych w dużej mierze późną tradycją zakonną jest cytat z pracy Wiesława Franciszka Murawca: „Klasztor na Karczówce posiadał uposażenie z nadania bp. Szyszkowskiego oraz kapituły katedralnej krakowskiej, nie wiemy wszakże, jakie. Do uposażenia należał również pokaźny zbiór biblioteczny, podarowany przez fundatora, liczący w roku przekazywania klasztoru bernardynom (1631) już 317 woluminów"6. Pomyłkowo znalazły się w tym stwierdzeniu dwie informacje. Po pierwsze bp fundował kościół, a nie klasztor i uposażył go wraz z obsadą plebańską, przekazując prawo patronatu kolegiacie kieleckiej i jej wikariuszom ${ }^{7}$. Po drugie księgi z daru biskupa, które znalazły się w posiadaniu bernardynów, przeszły do ich biblioteki dopiero po przejęciu kościoła (do którego mogły być przez biskupa/fundatora legowane - o czym będę pisał w dalszej części; nie mówiąc już o niewiarygodnie dużej liczbie woluminów, które miałyby trafić do małego kościoła z jednoosobową obsadą kapłana obsługującego miejscowych górników ${ }^{8}$. Najnowsze ustalenia i dokładna analiza zapisów źródłowych jednoznacznie wskazują na przybycie Braci Mniejszych Obserwantów na Karczówkę dopiero po śmierci fundatora

${ }^{4}$ Omówienie powodów fundacji i towarzyszących jej okoliczności zob.: W. K o w a ls k i, Biskup krakowski Marcin Szyszkowski a konsekwencje zarazy lat dwudziestych XVII stulecia, [w:] Człowiek i przyroda w średniowieczu i we wczesnym okresie nowożytnym, red. W. I w a ń c z a k i K. B r a c h a, Warszawa 2000, s. 227-244.

5 Obecnie odosobniona pozostaje teza G. Stobieckiej, jakoby bp M. Szyszkowski miał wysłać na kapitułę generalną bernardynów do Lublina w 1630 r. swojego delegata, który dopiero w lipcu miał ofiarować w imieniu fundatora kościół pw. św. Karola Boromeusza zakonnikom, zob. G. S t o b i e c k a, Pobernardyński zespót kościelno-klasztorny na Karczówce w Kielcach, „Rocznik Muzeum Świętokrzyskiego”, t. 8, 1973, s. 280.

${ }^{6}$ W. F. M u ra w i e c, Kielce, s, 134.

${ }^{7}$ Zob. J. M i c h t a, Poczatki fundacji, s. 17-28.

8 Zob. P. K a r d y ś, Szyszkowiana/pseudoszyszkowiana z dawnego księgozbioru bernardynów z Karczówki przechowywane obecnie $w$ zbiorach Biblioteki Wyższego Seminarium Duchownego w Kielcach, „Z Badań nad Książką i Księgozbiorami Historycznymi”, t. 12, 2018, s. 429-441. 
kościoła (zmarł w kwietniu 1630 r. ${ }^{9}$ ) pod wezwaniem św. Karola Boromeusza (najpewniej dopiero w $1632 \mathrm{r}$.) ${ }^{10}$. Mało tego, zachowane i znane obecnie dokumenty wyraźnie wspominają o sprzeciwie zarówno biskupa krakowskiego M. Szyszkowskiego, jak i papieża Urbana VIII co do osiedlenia się bernardynów na Karczówce ${ }^{11}$. Także źródła narracyjne proweniencji bernardyńskiej np. kronika o. Cypriana Damirskiego pisana w latach 1637-1651 informuje o fundacji bernardynów na Karczówce dopiero w $1631 \mathrm{r}^{12}$, podobnie podaje zresztą bernardyn o. Norbert Golichowski w swojej książce ${ }^{13}$. Ponadto inwentarz księgozbioru klasztornego z 2 poł. XVIII w. nie notuje darowizny bp. M. Szyszkowskiego spisanych w nim ksiąg.

Księgozbiór z Karczówki nie wzbudzał zainteresowania badaczy księgozbiorów zakonnych aż do końca drugiej dekady XXI stulecia. Spowodowane było to kilkoma zasadniczymi czynnikami. Przede wszystkim kasatą klasztoru w 1864 r., która była skutkiem represji carskich za pomoc powstańcom styczniowym.

9 E. O z o r o w s k i, Szyszkowski Marcin, [w:] Słownik Polskich Teologów Katolickich, t. 4, 1983, s. 296-298; K. R. P r o k o p, Poczet biskupów krakowskich, Kraków 1999, s. 157-160; A. B i edrzy cka, R. K aw e cki, Szyszkowski Marcin, [w:] Polski Stownik Biograficzny, t. 50, 2014-2015, s. 392-406.

${ }^{10}$ M. P i e n i ą ż e k - S a m e k, Kościót i klasztor na Karczówce w dobie nowożytnej; architektura $i$ wyposażenie, „Studia Muzealno-Historyczne” t. 4, 2012, s. 11-31; $\mathrm{S}$. B. T o m c z a k, Klasztory bernardyńskie $w$ Polsce $w$ jej granicach historycznych, [w:] Wkład bernardynów $w$ życie religijno-kulturalne narodu polskiego (wybrane aspekty), red. Cz. G n i e c k i, A. K. S i t n i k, Kalwaria Zebrzydowska 2016, s. 38.

11 Omówienie stanu badań, literatury i źródeł, zob. J. M i c h t a, Początki fundacji, s. 270-272. Autor przeanalizował ponownie dokumenty związane z fundacją i stwierdził, że powoływano się na rzekomą ustną zgodę bp. M. Szyszkowskiego, ponieważ nie zachowały się żadne dokumenty wystawione przez niego w tych sprawach (tj. fundacji bernardynów), a jego zgoda na fundacje klasztorów w diecezji była konieczna. Mało tego, próby przejęcia Karczówki J. Michta cofa do 1626 r., kiedy to bernardyni mogli rozpocząć działania mające na celu przejęcie miejsca kultu św. Karola Boromeusza i jego relikwii. Przytacza także niekorzystny dla bernardynów wyrok papieża Urbana VIII z 1629 r., w którym powołał się on na uzgodnienia z kardynałami i biskupem krakowskim. Kluczowa jest w tym przypadku własnoręczna zapiska dorsalna bp. M. Szyszkowskiego z 24 stycznia 1630 r. nakazującego w niej wykonanie polecenia papieskiego (Archiwum Diecezjalne we Włocławku, dok. perg. sygn. 1315).

12 O. Cyprian Da m i r s ki OFM, Kronika bernardynów w Polsce (1453-1651), przekł. o. K. Ż u c h o w s k i, Kalwaria Zebrzydowska 2016, s. 26, 40.

13 N. G o l i c how s k i, Przed nowa epoka. Materiały do historii oo. Bernardynów w Polsce, Kraków 1899, s. 70. 


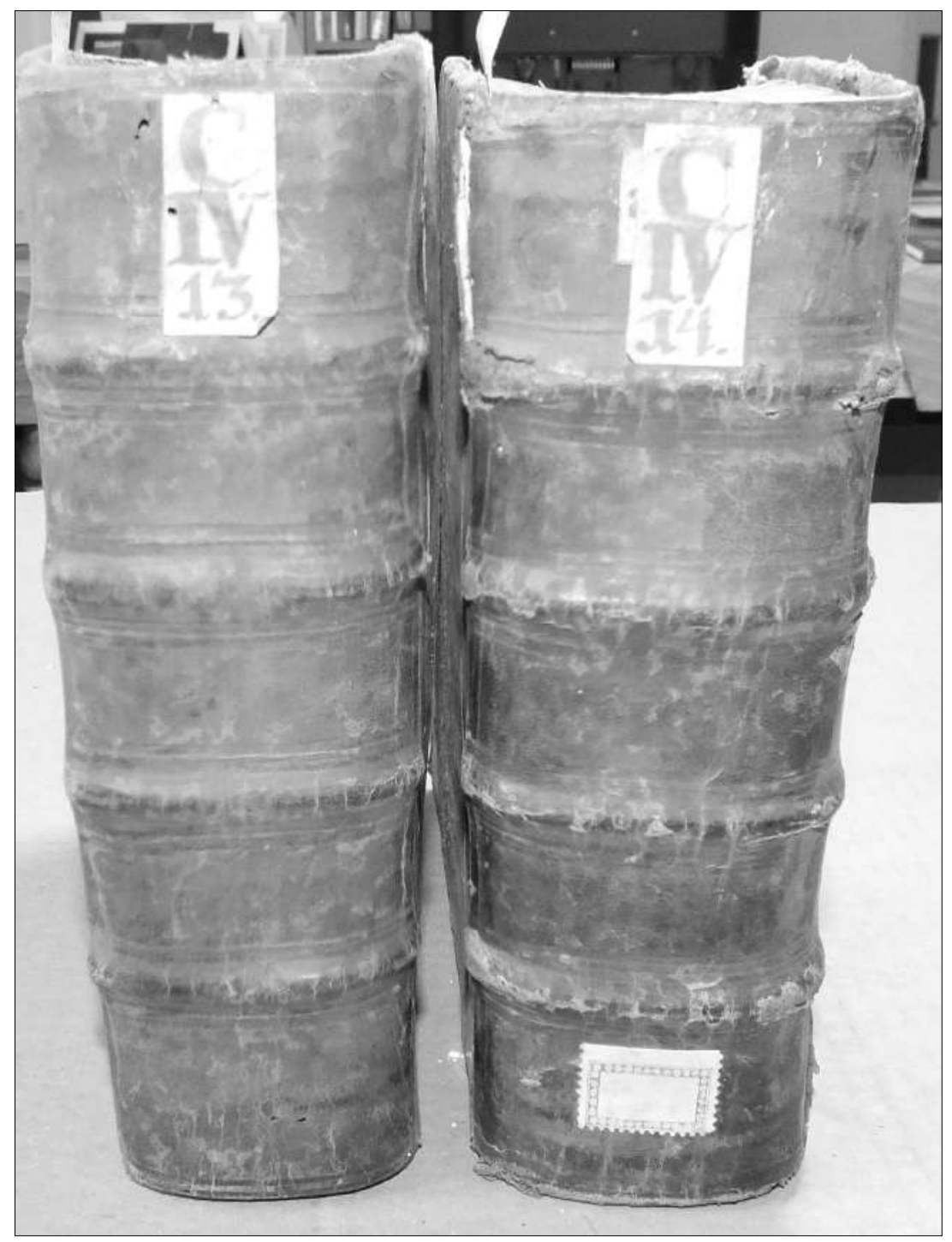

Woluminy z dawnej biblioteki bernardynów na Karczówce (obecnie BWSDK) z charakterystycznymi naklejkami inwentarzowymi 


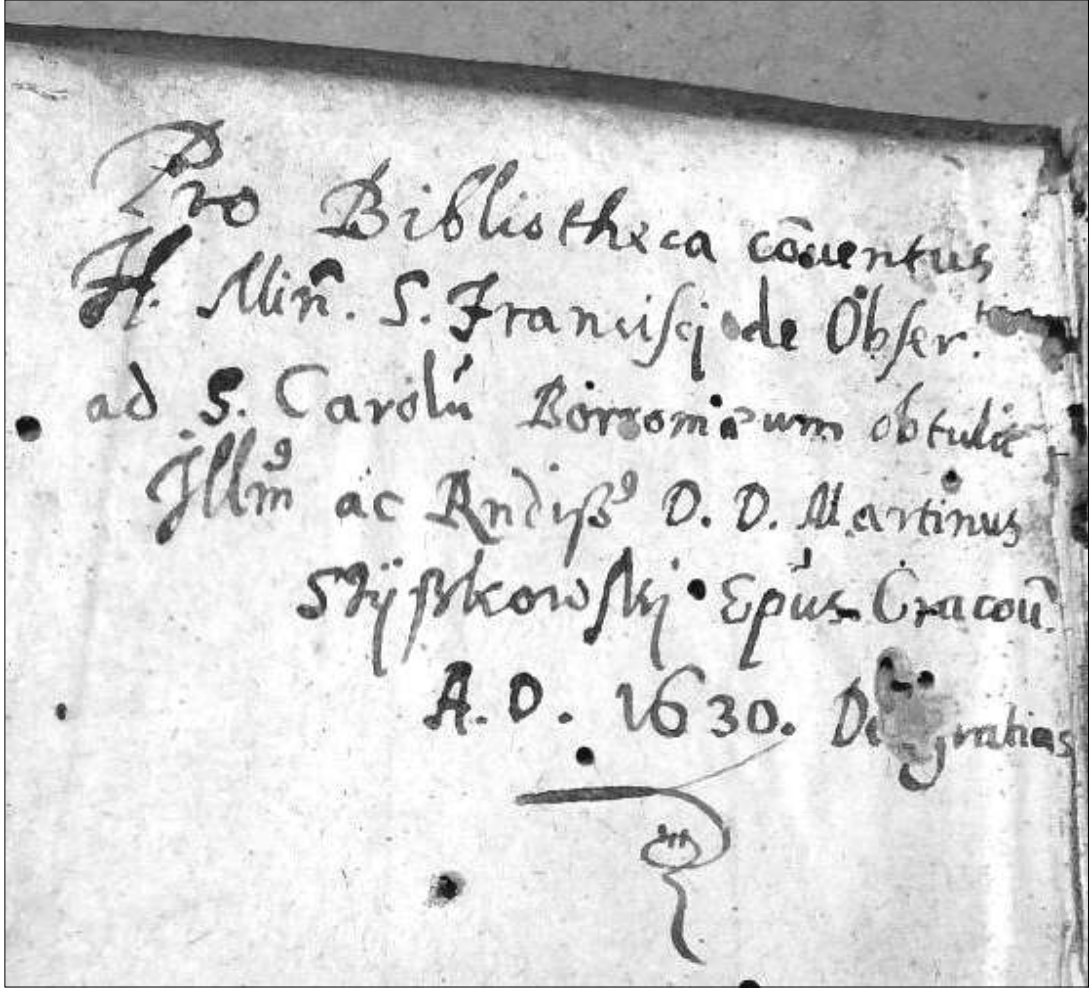

Wpis proweniencyjny przypisujący darowiznę woluminu dla konwentu na Karczówce bp. Marcinowi Szyszkowskiemu w 1630 r.

Ponadto faktem braku informacji o likwidacji biblioteki na Karczówce $\mathrm{i}$ jej ewentualnym przeniesieniu $\mathrm{w}$ inne miejsce, rozproszeniu, zniszczeniu czy sprzedaży. Wydaje się, że te dwa czynniki w największym stopniu zadecydowały o braku zainteresowania się tym tematem w 2 . poł. XX w. Były jednak także inne przesłanki, sugerujące, że badania nad dziejami tego księgozbioru nie przyniosą zadowalających rezultatów. Mam tu na myśli przede wszystkim opracowanie Kamila Kantaka dotyczące polskich bernardynów i relacje z działalności Samuela Bogumiła Lindego, który na rzecz Biblioteki Publicznej Królestwa Polskiego „wizytował" biblioteki instytucji kościelnych, zwłaszcza zakonnych mających podlegać kasacie, rekwirując bardziej wartościowe egzemplarze 
i podając przy okazji wiele ciekawych informacji o ich zawartości. Pierwszy $\mathrm{z}$ wymienionych ani razu nie wspomniał o księgozbiorze, który mógł istnieć na Karczówce, badania swoje bowiem oparł przede wszystkim na źródłach związanych z ważniejszymi konwentami funkcjonującymi na ziemiach dawnej Rzeczypospolitej Obojga Narodów ${ }^{14}$, czemu zresztą nie należy się specjalnie dziwić w sytuacji opracowania o charakterze syntetycznym i pionierskim. Także uzupełnienie opracowane przez Hieronima Eugeniusza Wyczawskiego, nie przyniosło nic nowego dla tej kwestii ${ }^{15}$. Z kolei w swoich sprawozdaniach S. B. Linde, który kilkukrotnie przebywał w Kielcach, skąd podróżował służbowo m.in. do Jędrzejowa, Wąchocka czy na Święty Krzyż, ani razu nie wspomniał, że istnieje pod Kielcami klasztor bernardyński, którego księgozbiorem byłby zainteresowany, chociaż sam pisał: „Ja zaś tu powtarzam dawniejszą uwagę, iż po tych drobnych biblioteczkach, a mianowicie bernardyńskich, reformackich, więcej znajdzie rzadkich rzeczy polskich niż po owych głośnych, co swoja sława niejednego lubownika alias złodzieja wabiły do siebie"16.

W okresie późniejszym, nawet jeśli wymieniano Karczówkę przy okazji opisów zabytków czy historycznych instytucji Kościoła, nie wspominano o ewentualnej bibliotece bernardyńskiej ${ }^{17}$. Nie wspomniał o niej także Emilian Lenart w swoim opracowaniu o bibliotekach bernardyńskich w Polsce ${ }^{18}$. W zasadzie nie powinno to dziwić, skoro nie zachowała się dokumentacja źródłowa sprzed kasaty, a jedynie w jednym z rękopisów przechowywanych w Archiwum

\footnotetext{
${ }^{14}$ K. K a n t a k, Bernardyni polscy, t. 1-2, Lwów 1933.

15 H. E. W y c z a w s k i, Bernardyni polscy, t. 3, 1772-1946, Kalwaria Zebrzydowska 1992.

${ }^{16}$ M. Ło dyń s ki, Materiały do dziejów państwowej polityki bibliotecznej $w$ księstwie Warszawskim i Królestwie Polskim (1807-1831), Wrocław 1958, s. 51. Pobyty w Kielcach zob. tamże: s. 52 i nn.

17 Zob.: E. C hwalewik, Zbiory polskie, archiwa, biblioteki, gabinety, galerie, muzea $i$ inne zbiory pamiątek przeszłości $w$ ojczyźnie $i$ na obczyźnie $w$ porzadku alfabetycznym wedtug miejscowości ułożone, t. 1, Warszawa-Kraków 1926-1927, s. 151; H. E. W y c z a w s k i, Zakon w Polsce, [w:] Klasztory bernardyńskie w Polsce w jej granicach historycznych, red. T e n ż e, Kalwaria Zebrzydowska 1985, s. 619-631.

${ }^{18}$ E. L e na rt, Biblioteki bernardyńskie $w$ Polsce od 2. połowy XV wieku do końca wieku XVIII, [w:] Pięćset pięćdziesiąt lat obecności oo. Bernardynów w Polsce (1453-2003), red. W. F. M u r a w i e c, D. A. M u s ku s, Kalwaria Zebrzydowska 2006, s. 659-677.
} 
Prowincji oo. Bernardynów w Krakowie znajduje się tylko częściowy inwentarz librari klasztoru na Karczówce ${ }^{19}$ z 2. poł. XVIII w. Jedyną wzmianką były krótkie informacje zawarte w informatorach o bibliotekach Kościoła katolickiego w Polsce, w których podawano, że w Bibliotece Wyższego Seminarium Duchownego w Kielcach (dalej: BWSDK) znajduje się dwanaście rękopisów z dawnej biblioteki na Karczówce, w tym graduał z pocz. XVI w., kancjonał z XVIII w. i różne traktaty teologiczne $\mathrm{z}$ tegoż stulecia ${ }^{20}$.

Poszukiwania wśród 10 tys. woluminów BWSDK pozwoliły na zlokalizowanie 329 woluminów, w których współoprawiono 354 tytu$\mathrm{ły}^{21}$. Wszystkie te księgi charakteryzują się bądź wpisami proweniencyjnymi wskazującymi jednoznacznie na przynależność do bernardynów na Karczówce, bądź posiadają charakterystyczne dla tegoż księgozbioru oznaczenia. Także w olbrzymiej większości były one ujęte w inwentarzu z 2. poł. XVIII w. Trzeba w tym miejscu podkreślić, że podane wyżej liczby są orientacyjne i maksymalnie zaniżone, gdyż brak nowoczesnego inwentarza lub katalogu z oznaczonymi proweniencjami uniemożliwia pełną kwerendę 10 tys. woluminów. Uwaga ta jest istotna, ponieważ z zachowanych sygnatur z Karczówki może wynikać, iż przez dawną bibliotekę bernardynów „przewinęło” się ok. 3 tys. woluminów. Autor niniejszego artykułu odnalazł także rękopis z dawnej biblioteki na Karczówce w Archiwum Diecezjalnym w Kielcach, co zdaje się świadczyć o rozproszeniu przynajmniej

\footnotetext{
19 Rkps, sygn. M-25, Chronologia ordinis Fratrum Minorum de Observantia Provinciae Minoris Polonia, Archiwum Prowincji oo. Bernardynów w Krakowie, s. 172-178: „Bibliotheca Conventus S. Caroli alphabeto conscripta”.

${ }^{20} \mathrm{R}$. N i r, Informator o archiwach, bibliotekach $i$ muzeach kościelnych $w$ Polsce, „Chrześcijanin w świecie” nr 56/57, 1977, s. 199-227; T e n ż e, Katalog rękopisów Biblioteki Seminarium Duchownego w Kielcach, „Archiwa Biblioteki i Muzea Kościelne" (dalej: ABMK) t. 40, 1980, s. 329-400; t. 41, 1980, s. 91-126; Zbiory rękopisów $w$ bibliotekach $i$ muzeach $w$ Polsce, oprac. D. K a m o low a przy współpr. K. M u s z y ń s k i e j (zbiory kościelne), Warszawa 1988, s. 67; Biblioteki Kościoła katolickiego w Polsce. Informator, oprac. W. Ż u r e k, Kielce 2005.

${ }^{21}$ Badania przeprowadziłem dzięki pomocy Dyrektora BWSDK ks. dr. Adama Wilczyńskiego oraz p. Arlety Nersesyan i p. Karoliny Wychowaniec. Było to duże przedsięwzięcie, gdyż w katalogu kartkowym brak informacji o zachowanych proweniencjach z Karczówki. Musiano m.in. dokonać przeglądu w magazynie dubletów, dla którego nie ma katalogu kartkowego. Wskazówką do poszukiwań były ustalone przeze mnie cechy zewnętrzne woluminów z dawnej biblioteki bernardynów.
} 
części dawnego księgozbioru, zanim wszedł on do BWSDK w wyniku kasaty klasztoru ${ }^{22}$.

W zakresie podziału starodruków i jednego odnalezionego inkunabułu z dawnej biblioteki bernardyńskiej należy podkreślić, że na XV stulecie przypada 1 pewny tytuł $\mathrm{i}$ ewentualnie 1 rękopis liturgiczny datowany od końca XV do 1 poł. XVI stulecia. Na wiek XVI składają się 63 tytuły, na XVII 173, zaś na XVIII 116 tytułów ${ }^{23}$. Wynika z tego, że układ jest klasyczny dla księgozbiorów Kościoła na ziemiach polskich z okresu walki $\mathrm{z}$ reformacją i zgodny $\mathrm{z}$ wytycznymi Soboru Trydenckiego, a także podobny do księgozbioru bernardynów krakowskich ${ }^{24}$, który w przypadku Karczówki i całej małopolskiej prowincji musiał być swego rodzaju wzorem do naśladowania.

Analiza tematyki zachowanego księgozbioru również potwierdza jego typowość i pozwala podzielić go na następujące działy: Biblia, konkordancje i komentarze Pisma Świętego; Ojcowie Kościoła, doktorzy i pisarze kościelni; kaznodziejstwo, teologia scholastyczna, moralna i kontrowersyjno-polemiczna; prawo kanoniczne i cywilne; historia, historiografia, hagiografia; reguły zakonne, monastica; piśmiennictwo ascetyczne i mistyczne; filozofia, matematyka i nauki przyrodnicze, humanistyka i medycyna. Trzeba jednak w tym miejscu zaakcentować, iż woluminy nie mogły być w taki sposób ułożone w szafach bibliotecznych, ponieważ sygnatury, które zachowały się na oprawach w postaci naklejonych karteczek inwentarzowych od litery A do E, pokazują jak w praktyce wyglądał podział w bibliotece bernardynów na Karczówce. Pod literą A skoncentrowała była literatura fachowa/praktyczna - katechizmy, reguły zakonne, kanony i dekrety, podręczniki liturgiczne i kwestie teologiczne.

\footnotetext{
22 Zob. P. K ardy ś, Patrum, s. 19 i Katalog C 43. Zachowała się także informacja o sporze wokół biblioteki z Karczówki ostatnich zakonników na Karczówce: o. Kolumbina Tomaszewskiego i gwardiana Stanisława Grzybowskiego. Książki miały być po części sprzedane za 30 rubli srebrnych lub gdzieś odesłane, zob.: C. J a s t r z ę b s k i, Kasata, s. 40-41. Mimo wszystko najprawdopodobniej do kasaty wciąż pozostawał przynajmniej w części dawny księgozbiór, o czym może świadczyć wpis w jednej z książek, należącej właśnie do ostatniego zakonnika - o. Kolumbina, zob. P. K a r d y ś, Patrum, s. 15 i Katalog B 10. Możliwe, że nabywców znalazły druki najnowsze, a co za tym idzie najbardziej aktualne, gdyż w zrekonstruowanym księgozbiorze nie ma ani jednej książki z XIX w.

${ }^{23}$ P. K a r d y ś, Patrum, s. 80-81.

${ }^{24}$ W. F. M u r a w i e c, Księgozbiory krakowskie, s. 43.
} 


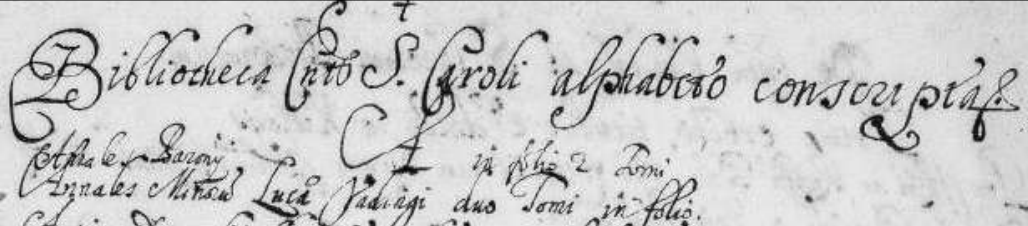

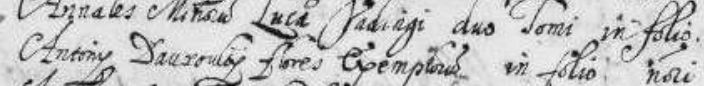

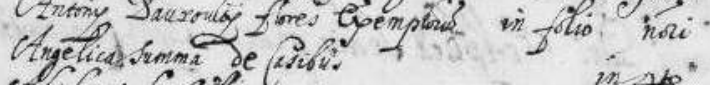

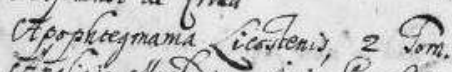

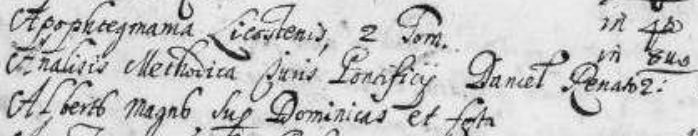

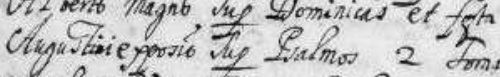

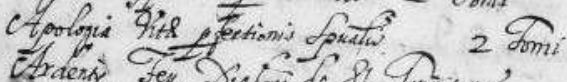

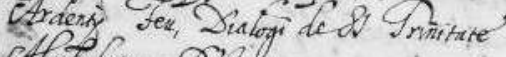
Ctfotaberam fristi Alyoviare ses Tomi

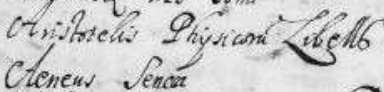

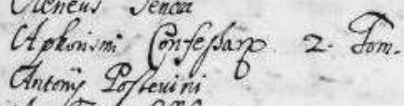

ctugustini Solicequia

Afami Sosta.

ctademia prituhs

Akify verani de 7 lifif eiderys

Siblus arina in ofis

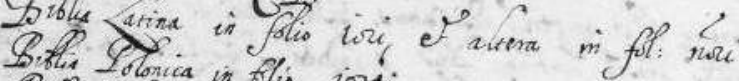

\&o Dofica in filio iori:

Giblia Ninna due Pomi in fol the

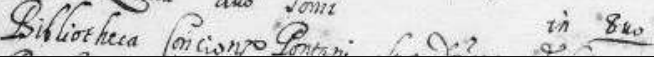

Początek inwentarza biblioteki bernardynów na Karczówce 
Pod B zinwentaryzowano prawo kanoniczne, teksty i komentarze do odpustów i jubileuszy, kwestie dogmatyczne, sumy teologiczne, komentarze do Ewangelii i Pisma Świętego, kwestie sporne z protestantami. Pod C szeroko rozumianą pobożność, pod D zbiory kazań i pomocy do ich konstruowania, zaś pod E poloniki i zbiory kazań polskich autorów ${ }^{25}$. Ogólny wniosek jest następujący: była to typowa dla tego okresu i miejsca biblioteka wspólnoty Ordo Sancti Francisci Fratrum Minorum de Observantia z przewaga praktycznej literatury kaznodziejskiej i teologii moralnej, gromadzona z przeznaczeniem dla pracy duszpasterskiej przy jednoczesnej dbałości władz zakonnych o obecność najważniejszych dzieł dla formacji intelektualnej i duchowej ojców oraz braci.

Niewątpliwie najważniejszą i najcenniejszą część księgozbioru z Karczówki stanowią starodruki, których proweniencja może wskazywać na darowiznę bp. krakowskiego M. Szyszkowskiego, fundatora kościoła pw. św. Karola Boromeusza. Ponieważ były już przedmiotem mojego szczegółowego opracowania, krótko podsumuję w tym miejscu moje wcześniejsze ustalenia ${ }^{26}$. W trakcie poszukiwań w BWSDK natrafiłem na siedem starodruków z wpisem proweniencyjnym o następującej treści: „Pro Bibliotheca FF. Minorum S. Francisci de Observantia Conv[entus] S. Caroli Borromaei obtulit Illustrissimus ac Reverendissimus Dominus Martinus Szÿszkowski Episcopus Cracoviensis AD 1630 Deo Gratias" ${ }^{27}$. Wobec faktu sprzeciwu bp. krakowskiego, co do osadzenia bernardynów na Karczówce za jego życia niemożliwa jest darowizna dla tychże notowana w roku 1630. Jedynym logicznym wytłumaczeniem tego rodzaju wpisów proweniencyjnych może być fakt przejęcia po $1631 \mathrm{r}$. książek darowanych przez biskupa - fundatora kościoła św. Karola Boromeusza. Istnieje jeszcze inne możliwe wy-

\footnotetext{
${ }^{25}$ Zob. P. K a r d y ś, Patrum, s. 92-93.

${ }^{26}$ T e n ż e, Szyszkowiana/pseudoszyszkowiana, s. 429-441.

27 VVan P a u lus, Promptuarium Sermonum Dominicalium totius anni, Coloniae 1613, zob. T e n ż e, Patrum, Katalog E 3; Bosquier Philippus, Legatus Apostolicus seu Concionum, de Johannis Baptistae..., Coloniae 1612; Codrus Evangelicus seu concionum XL, Coloniae 1614; Sobria Ientacula Christi et Samaritanae..., Coloniae 1612, tamże, Katalog BS 16, 17, 19; Camusio Joanne P i e tr o, Primae homiliae quadragesimales et in passione Domini Nostri Jesu Christi, Coloniae Agrippinae 1621, tamże, Katalog BS 25; Lusitani Andrea Eborensis, Sententiarum Memorabilium, cum Ethnicarum Christianarum ex Probatissimi quibusque..., Moguntiae 1609, tamże, Katalog BS 59.
} 
thumaczenie. Otóż bernardyni mogli celowo dokonać wpisów o treści jednoznacznie sugerującej fundację ich klasztoru przez bp. M. Szyszkowskiego, aby w późniejszej tradycji zgromadzenia można było powoływać się na te ,bezsporne dowody” w obliczu braku autentycznych dokumentów fundacyjnych. Obie hipotezy są równouprawnione, zwłaszcza wobec faktu, iż $\mathrm{w}$ wielu innych przypadkach dokonano wpisów proweniencyjnych, wielokrotnie tą samą ręką, z taką samą datą, tj. 1630 oraz $\mathrm{z}$ datą 1632 r. Wynika $\mathrm{z}$ tego, że bez względu na datę wpisy pochodzą nie wcześniej niż z 1632 r., co zgadzałoby się z faktycznym czasem przejęcia Karczówki przez bernardynów i stabilizacją wspólnoty oraz organizacją pierwszej biblioteki. Mało tego, w dwóch starodrukach znajduje się wpisana wspomnianą wyżej ręką proweniencja przypisująca darowiznę bratankowi biskupa krakowskiego - Mikołajowi Szyszkowskiemu, sekretarzowi wielkiemu koronnemu, późniejszemu biskupowi warmińskiemu: „Pro Conventu Montis S[ancti] Caroli Boromaei PP. Bernardinorum ab R. D. Nicolao Szyszkowski Secretario Regni fundatore applicatur pro Bibliotheca Kielcys A.D. $1632 " 28$. Mimo że wpis o takiej treści znalazł się tylko w dwóch woluminach, możemy być pewni, że jeśli była to faktyczna darowizna, musiała obejmować co najmniej sześć woluminów, gdyż obecnie udało się zlokalizować w BWSDK kolejne cztery woluminy/tomy tego samego autora Jana $\mathrm{z}$ Kartageny, wydane w zbliżonym czasie i mające identyczne oprawy, zatem pochodzące $\mathrm{z}$ jednorazowej donacji ${ }^{29}$.

Kolejne „krakowskie” starodruki to przede wszystkim w olbrzymiej większości te z proweniencjami datowanymi na lata 1630 i 1632. W sumie możemy wskazać jedenaście dzieł w dziesięciu woluminach

\footnotetext{
28 Joannis de $\mathrm{C}$ a r th a g e n a, Opera. Homiliae in Universa quatuor tomus distincta, tomus quartus, Coloniae Agrippinae 1626; Homiliae Catholicae de sacris Arcanics Deiparae Mariae et Jospehi, tomus primus, Coloniae Agrippinae 1625, P. K a r d y ś, Patrum, Katalog D 33, D 38.

29 Joannis de Car t h a g e n a, Homiliae Catholicae in universa Christianae Reliogionis Arca in Libros XVI, Coloniae Agrippinae 1614; Homiliae Catholicae, tomus primus, Coloniae Agrippinae 1613; Homiliae Catholicae, tomus secundus, Coloniae Agrippinae 1618; Homiliae Catholicae, tomus tertius, Coloniae Agrippinae 1616, tamże, Katalog D 34, D 35, D 36, D 37. Należy także przypomnieć, że po śmierci stryja Marcina, Mikołaj zarządzał jeszcze przez dwa lata diecezją krakowską, zob. K. N i e s i e c ki, Herbarz Polski, t. 8, Lipsk 1848, s. 650-651; A. B i e d r z y c k a, Szyszkowski Mikołaj, [w:] PSB, t. 50/3, z. 206, Warszawa-Kraków 2015, s. 406-413.
} 
z 1630 r. ${ }^{30}$ i dwadzieścia dwa dzieła w dwudziestu jeden woluminach z $1632 \mathrm{r}^{31}$. Warto zauważyć, że wszystkie te tytuły prezentują typowy obraz biblioteki bernardyńskiej tamtego czasu, ze względu na formację intelektualną, duchowość i zadania duszpasterskie. Oznacza to, że

${ }^{30}$ Bosquier P h i l i p p u s, Vegetius Christianus seu Scipionis Renati Insomniorum libri sex, Coloniae Agrippinae 1615, współoprawne Bosquier P h i li p p u s, Orator Terrae Sanctae, Coloniae Agrippinae 1611, tamże, Katalog D 10; Baldvini I u n i i, Manuale Thelogicum, Moguntiae 1615, tamże, Katalog D 8; Nucelus C o p p e n s t e i n i ex conceptibus Besseanis, In Dominicas omnes per annum, Moguntiae 1618, tamże, Katalog D 40; Friderico F o r n e ro, Rex Hebronensis ac postea. Hierosolomitanus Poenitentis schemate Personatus. Psalmus L. Miserere Mei Deus, Ingolstadii 1615, tamże, Katalog BS 43; Gonzaga F r n a c s c o, De origine seraphice religionis franciscanae, Venetis 1603, tamże, Katalog BS 43; Petro de Palude, Sermones sive ennarationes in Evangelia, pars hiemalis, moguntiae 1608, tamże, Katalog BS 73; Joanne R o u s s e r i u s, Status et Origo Sacratissimi Ordinis S. Francisci, Parisiis 1610, tamże, Katalog BS 97; Adriani M a n g t i i, Monita Sacra es S. Sriptura et SS. Patribus potissimum Collecta, pars tertia, Antverpiae 1615, tamże, Katalog BS 66 i przyp. nr 33-34, 38.

31 Johannes Th a u le r, Exercitia De Vita et Passione Salvatoris Nostri Jesu Christi, Coloniae 1607, tamże, Katalog A 4; Guillelmus Du r a n d u s, Rationale Divinorum Officiorum seu enchiridion, pars 1-2, tomus primus, Lugduni 1612, tamże, Katalog A 18; Petro B e s s e o, Regale Sacerdotium, libri tres, Coloniae Agrippinae 1615, tamże, Katalog A 21; Emanuele Sa L u sita n o, Aphorismi Confessariorum ex Doctorum sententijs collecti, Coloniae 1609 i 1612, tamże, Katalog B 4, B 5; Philippus Diez L u s i t a n u s, Concionum super Evangelia, que a Dominica..., Coloniae Agrippinae 1604, tamże, Katalog D 19; Jacobi de V o r a g i n e, Sermones de sanctis per anni totius circulum, Venetis 1602, T e nż e, Sermones dominacales per totum annum, Venetiis 1602, tamże, Katalog E 2, BS 123; Alberti M a g n i, Sermones in Dominicas, festaquae per annum, Opera Joannis Andreae Coppenstein, t. 1-2, Moguntiae 1615 i współoprawne Joannes Andreae Coppenste in, Passionis Domini nostri Jesu Christi quadripartitae, Moguntiae 1615, tamże, Katalog D 4; Bosquier P h i 1 i p p u s, Orbis Terror seu Concionum de Finibus Bonorum et Malorum, Libri duo, Coloniae Agrippinae 1610, tamże, Katalog BS 15; Joannes Petrus Ca musius, Sermones sublimati seu Homiliae Dominicales et Festivales, Coloniae Agrippinae 1619, tamże, Katalog BS 24; Jacobo Gordono Hubtleao S c oto, Controversiarum Christianae Fidei adversus huius temporis haereticos epitome, Coloniae Agrippinae 1620, tamże, Katalog BS 50; Didaci M u r i 11 o, Conciones Quadragesimales, Coloniae Agrippinae 1612, tamże, Katalog BS 70; Joannes R a u 1 i n, Opera Omnia, quae Inveniri Potuerunt. Omnia Sermonum Quadragesimalium, Antverpiae 1612, współoprawne Joannes R a u 1 i n, Sermones Dominicales, Antverpiae 1612, tamże, Katalog BS 83; T e n ż e, Sermonum quadragesimalium, pars prima - pars secunda, Antverpiae 1612, tamże, Katalog BS 84; Luca W a d ing o, Annales Minorum, tomus secundus, Lugduni 1628, tamże, Katalog BS 116; Antonio Fernandes de M o u r e, Examen Theologiae Moralis Medullam, Coloniae Agrippinae 1618, tamże, Katalog PBS 8 i przypisy nr 35-37, 39. 
W większości pochodziły one z macierzystego krakowskiego konwentu, ale również od kanoników kolegiaty pw. św. Floriana ${ }^{32}$. Były to przywileje i statuty franciszkańskie, reguły zakonne, najważniejsze i najpopularniejsze zbiory kazań i exemplów, komentarze do Pisma Świętego i Psalmów, sentencje, żywoty Jezusa i świętych, pomoce duszpasterskie i do zarządzania parafią, sumy i kwestie z teologii moralnej oraz polemiczno-kontrowersyjnej ${ }^{33}$.

Ich ogromne znaczenie dla nowo założonej wspólnoty potwierdzają niektóre wpisy z informacją, kiedy dokładnie i w jaki sposób mają być poszczególne dzieła używane. I tak do codziennego wykorzystywania przez superiora wspólnoty na Karczówce przekazano zbiór przywilejów franciszkańskich i kompendium objaśniające reguły: „Pro loco Montis S[ancti] Caroli A.D. 1630. Pro loco Montis S[ancti] Caroli PP. Bernardinorum ad cellam V.R. Superior[um] obligat [...] 1630"34. Z kolei w dziele Manuela Rodrigueza zapisano: „Pro Conventu S[ancti] Caroli Boromaei. Pro cella P. Gvardiani Con[ventus] S[ancti] Caroli Kielcijs Brnard[inorum] 1632"35. Podobnie było w przypadku Światła duszy Brtholomaei Saluti: „Pro cella Vicar[ii] Conventus S[ancti] Caroli PP. Bernardinorum 1632",36.

Z jeszcze wyraźniejszym wskazaniem przeznaczenia dla całej wspólnoty na Karczówce i do wykorzystania podczas głośnej lektury formacyjnej w refektarzu, spotykamy się w przypadku darowizn Studium doskonatości Crombeciusa i Duchowego przewodnika Ludovica de Ponte: „Pro pulpito Refector[ii] ad S[ancti] Caroli Con[ventus] Kielcyjs PP. Bernard[inorum] AD 1632,"37.

\footnotetext{
${ }^{32} \mathrm{Na}$ temat kolegiaty pw. św. Floriana, zob.: B. K u m o r, Dzieje diecezji krakowskiej do roku 1795, t. 2, Kraków 1999, s. 361-397.

33 Szczegółowe omówienie księgozbioru z Karczówki pod kątem autorów i tematyki, zob.: P. K a r d y ś, Patrum, s. 84-94.

${ }^{34}$ Alphonso de C a s a r u b i o, Compendium Privilegiorum Fratrum Minorum, Coloniae Agrippinae 1619 i współoprawne Emanuel Rodericus Lusitanus, Compendium Questionum Regularium, Coloniae Agrippinae 1618, P. K a r d y ś, Patrum, Katalog BS 27.

${ }^{35}$ Manuel R odrigue z, Summa casuum conscientiae, Coloniae Agrippinae 1620, tamże, Katalog B 26.

${ }^{36}$ Bartholomaei S a lut i, Lux Animae ad perfectionem anhelantis, Coloniae 1613, tamże, Katalog C 15.

${ }^{37}$ Ludovico de Ponte V a 11 is - O le t a n o, Dux Spiritualis, Coloniae Agrippinae 1613, tamże, Katalog C 8; Johannes C r o m b e c i u s, De Studio perfectionis libri duo, Moguntiae 1614, tamże, Katalog C 18.
} 


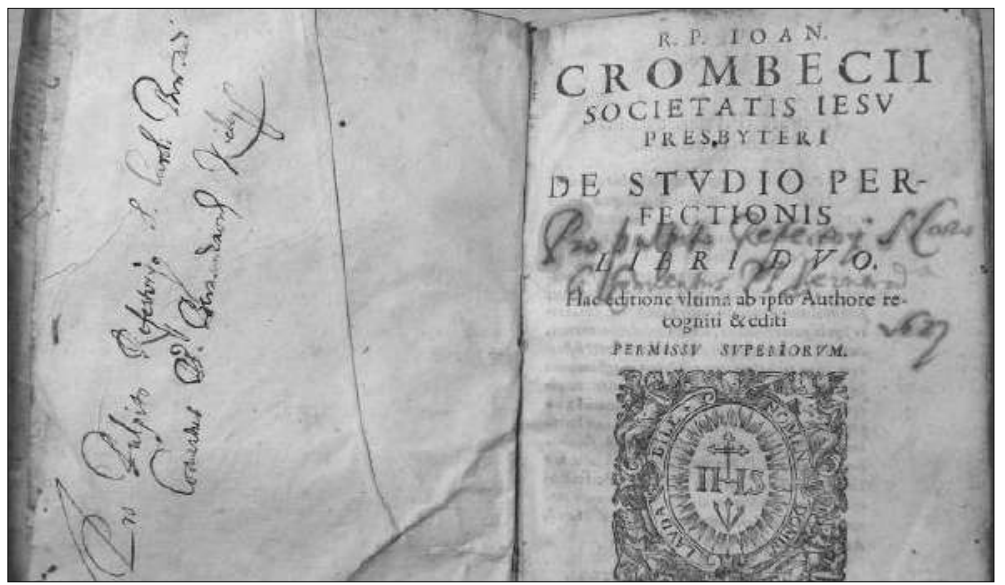

Johannes Crombecius, De studio perfectionis..., wpis informujący o przeznaczeniu do refektarza na Karczówce w 1632 r.

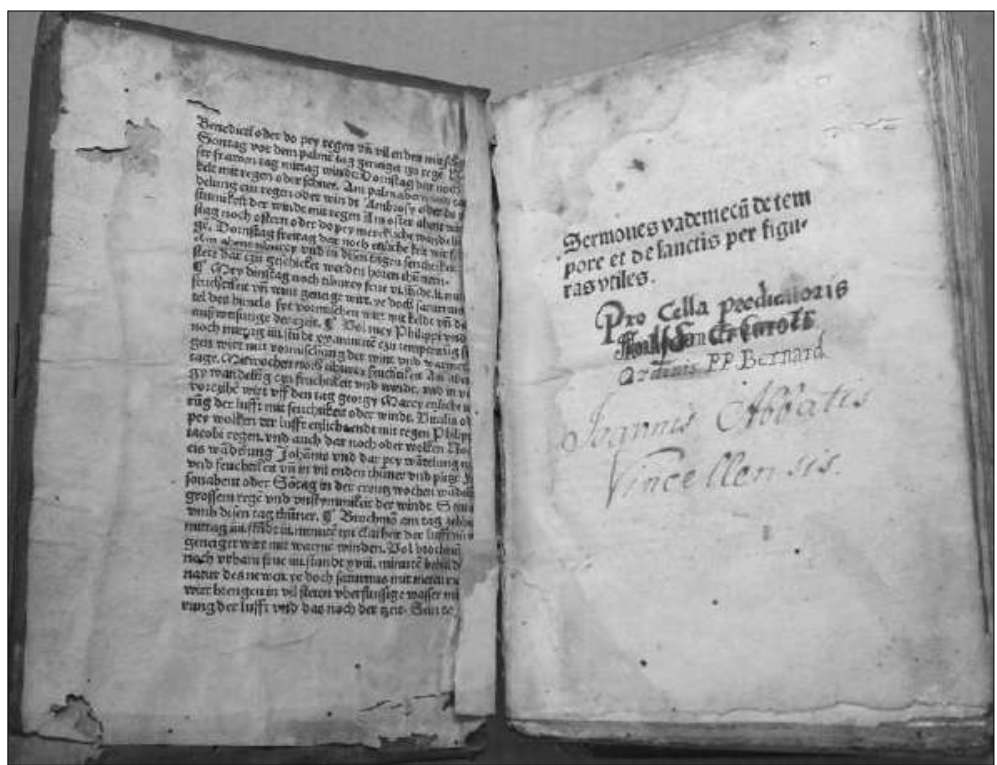

Sermones Joannis Abbatis Vincellensis, z wpisem „Pro cella preadicatoris” konwentu św. Karola 
Inne darowizny, np. ministra prowincji polskiej i superiora ze Lwowa, którzy przekazali na Karczówkę powszechnie znane w Kościele i często wykorzystywane Mariale Bernardyna de Bustis czy Jana Raulina: „Pro Conventu S[ancti] Caroli Boromaei alias na Karczowke. Frater Feliciae Kazimir Leopoli defunctae superiorum permissu Fr[ater] Kamynski Ord[ini] de Observ[antia] in signum amoris oblatum 1630"38, „Pro Conventu S[ancti] Caroli PP. Bernardinorum ab D. R. P. Joanne [...] Ministro Prov[incie] Poloniae dignis [...] ad Bibliothecam 1632" "39, potwierdzają znaną z literatury i źródeł praktykę „rozdysponowania” książek, prowadzoną w tym zakonie odgórnie ${ }^{40}$.

Wśród wymienionych wyżej woluminów, znajduje się siedem, w których zachowały się proweniencje Alberta/Wojciecha, wiceprepozyta

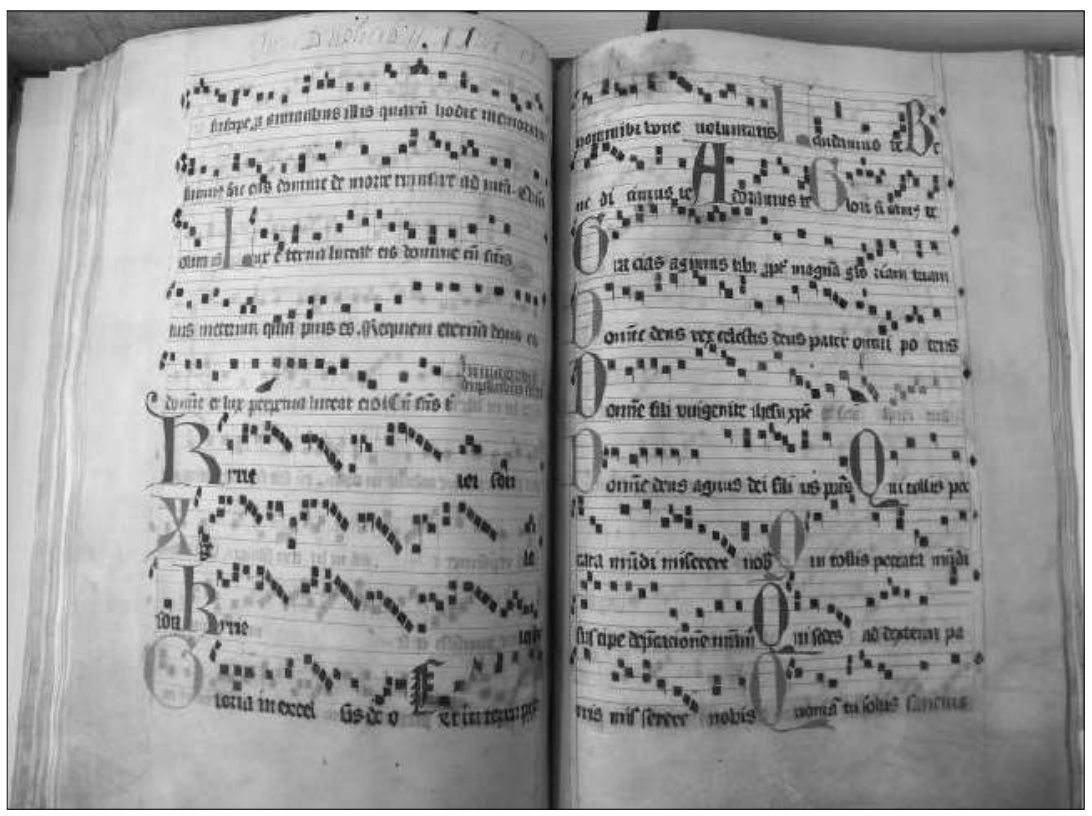

Graduał bernardyński z Karczówki, XV w.(?)/pocz. XVI w.

${ }^{38}$ Bernardino de B u s t o, Mariale seu sermones De Beatissima Virgine Maria, tomus tertius, Coloniae Agrippinae 1607, tamże, Katalog BS 13.

${ }^{39}$ Joannes Raulin, Sermonum de Sanctis, pars prima, Antverpiae 1611, tamże, Katalog D 15.

${ }^{40}$ P. K a r d y ś, Patrum, s. 68-70. 
kolegiaty pw. św. Floriana w Krakowie, ponadto posiadających także sygle F.G.Z. na stronach tytułowych. Obecny stan badań nie pozwala odpowiedzieć na pytanie, czy najpierw starodruki te weszły do księgozbioru krakowskiego, skąd później trafiły na Karczówkę, czy od razu zostały przekazane do nowo powstałego konwentu od kanonika św. Floriana, ponieważ nie dysponujemy opracowaniem biblioteki bernardynów krakowskich. Wpisy w rodzaju: „Ex Libris Adalberti vicepraepositi S[ancti] Floriani”, „Albertus vicepraepositus Sancti Floriani”, wyżej wymienione sygle oraz treść „Pro loco...” dokonano tą samą ręką ${ }^{41}$, zatem możemy stwierdzić, że wcześniej prawdopodobnie aż siedem woluminów (osiem dzieł) należało do owego kanonika krakowskiego. I w tym miejscu możemy zauważyć pewną prawidłowość, bowiem studium nad darczyńcami książek dla klasztoru krakowskiego wykazało ścisłe związki kanoników krakowskich, zwłaszcza z kolegiaty św. Floriana $\mathrm{z}$ bernardynami ${ }^{42}$.

Nie ulega wątpliwości, wobec faktu identycznych lub bardzo podobnych wpisów proweniencyjnych z lat 1630 i 1632, że w olbrzymiej większości starodruki te pochodziły z klasztoru macierzystego w Krakowie, gdzie zapewne stanowiły dublety, a z punktu widzenia potrzeb nowo organizowanej wspólnoty były niezbędne. Praktyką było bowiem kompletowanie księgozbioru od początków funkcjonowania konwentów. Mówiły o tym bardzo wyraźnie przepisy kapituł generalnych i prowincjonalnych bernardynów, począwszy od XV w. ${ }^{43}$,

\footnotetext{
${ }^{41}$ Zob. ibid., s. 29-31.

${ }^{42}$ W. F. M u raw i e c, Księgozbiory, s. 50-51 i W. S z eli ń s k a, Krakowski kata$\log$, s. $211-217$.

${ }^{43}$ K. K a n t a k, Bernardyni, t. 1, s. 300-301; T e n ż e, Capitula nec non Constitutiones FF. Minorum Observantiam (Bernardinorum) Provinciae Poloniae 1453(1467) 1628, „Collectanea Theologica” 15, 1934, nr 4, s. 459-462; T e n ż e, Kapituly i Konstytucje bernardyńskie w XV i XVI w., „Przegląd Teologiczny” 10, 1929-1932; H. E. W y c z a w s k i, Statuty zakonu Bernardynów w Polsce 1453-1795, „Prawo Kanoniczne" 25, 1982, z. 1-2, s. 179-196; W. F. M u r a w i e c, Księgozbiory krakowskie zakonu Braci Mniejszych - bernardynów i reformatów - w świetle not proweniencyjnych $w$ XVI-XVIII $w$., „Folia Historica Cracoviensia” 2, 1994, s. 41-59; T e nż e, Księgozbiory $i$ książki rękopiśmienne $w$ prawodawstwie ogólnym Zakonu Braci Mniejszych w późnym średniowieczu, tamże 6, 1999, s. 49-61; T e n ż e, Początki biblioteki konwentu krakowskiego pw. św.. Bernardyna ze Sieny, tamże 7, 2000, s. 93-111; E. L e n a r t, Biblioteki, s. 659-677; K. Ś 1 a s k a, Funkcja książki w zakonie bernardynów w XVII w., „Z Badań nad Polskimi Księgozbiorami Historycznymi" 13, 1991, s. 132;
} 
a skończywszy na poprzedzającej fundację na Karczówce kapitule w Kalwarii Zebrzydowskiej (1623 r.). Także określniki w rodzaju ,assignat" zdają się potwierdzać tezę, o ich rozdysponowaniu z biblioteki macierzystego konwentu.

Władze zakonne od początku kładły nacisk na użyteczność księgozbiorów w codziennej pracy, dbałość o ich zawartość, o uzupełnianie aktualnych treści, bieżące inwentaryzowanie i katalogowanie oraz o odpowiedni stan ich zachowania. Spisane w zbliżonym do fundacji Karczówki okresie dwa artykuły konstytucji bernardyńskich (XIII i XIV), podkreślały nie tylko rolę superiora prowincji w zakresie
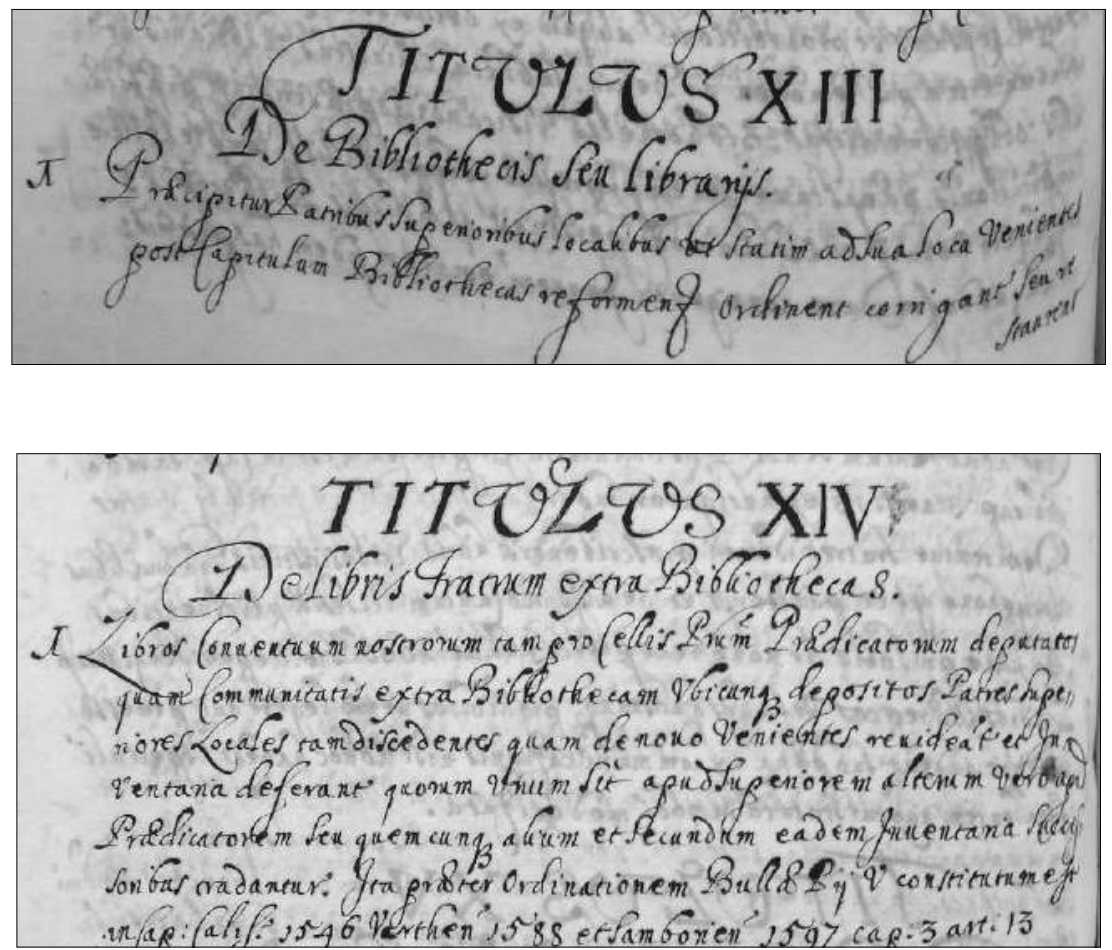

Art. XIII i XIV dotyczące organizacji bibliotek i sposobów korzystania z księgozbiorów u bernardynów 
kontroli nad bibliotekami konwentów, ale również nakazywały odpowiednią dla potrzeb wspólnoty jej organizację, wyznaczały odpowiedzialne osoby i określały zasady korzystania z księgozbiorów, itd. ${ }^{44}$.

Najprawdopodobniej „krakowskim” woluminem w księgozbiorze z Karczówki jest także Gradulae Romanum. Sporządzony gotycką teksturą z końcem XV w. lub na pocz. XVI w., bogato zdobiony złoconymi inicjałami i marginaliami florystycznymi (skryptor i iluminator nieznani), ponadto zawierający Proprium de Tempore, de Sanctis, Commune Sanctorum, Missae pro Defunctis, Ordinarium Missae i sekwencje - wszystko to pozwala uznać jego zawartość za typową dla liturgii bernardyńskiej ${ }^{45}$. Tym samym prawdopodobne jest stwierdzenie, że wykonano go w skryptorium krakowskim ${ }^{46}$. Zapewne graduał ten był jednym z najważniejszych rękopisów liturgicznych niezbędnych dla funkcjonowania nowej wspólnoty.

Kolejnym „krakowskim” legatem książkowym były komentarze do listów św. Pawła do Rzymian autorstwa Dominika Soto, które przekazał na Karczówkę również kanonik kolegiaty pw. św. Floriana - prepozyt Marcin z Wadowic, wicekanclerz wydziału teologicznego uniwersytetu krakowskiego: „Montis S[ancti] Caroli Conventus PP. Bernardinorum. Usui Fr[atr]is Praeclai a Magni, ac An[no] D[omi]ni Martino de Wadowice Praep[ositu]s S[ancti] Floriani Crac[oviae] in Clepar[dia] Professoris S[anctae] Theologiae Academiae Crac[oviensis] Vice Cancel[larius] Theologiarum Praestantissimi"47. Charakter wpisu proweniencyjnego (zarówno pismo i treść) wskazują na podobieństwo do wielu innych datowanych na ok. poł. XVII w. ${ }^{48}$.

\footnotetext{
44 Muzeum Narodowe w Krakowie, Biblioteka Książąt Czartoryskich, rkps sygn. 11802 (dawna: Ed XVII/2469), Anagryphe seu compendiosa descriptio Provinciae Poloniae Fratrum Minorum Observantium tam administrationis officia quam acta regiminis eiusdem provinciae concernentia complectens. Authoritate et mandato Superiorum hoc compendioso expressa stylo Anno Domini 1651, s. 392-395: „Titulus XIII. De Bibliothecis seu librarijs”, „Titulus XIV. De libris Fratrum extra Bibliothecas”.

45 Tak E. L e n a r t, Katalog bernardyńskich rękopisów liturgicznych $w$ Polsce od XV do XVIII wieku, ABMK 53, 1986, s. 244-245, nr 241.

${ }^{46}$ P. K a r d y ś, Patrum, Katalog BS 88 (BWSDK, sygn. RL-6).

47 Dominici S oto, In Epistolam Divi Pauli ad Romanos commentarii, Antverpiae 1550 , tamże, Katalog D 43.

${ }^{48}$ Wykaz woluminów z proweniencją z ok. poł. XVII w. i charakterystyczną dla XVII w., zob. tamże, s. 32-36.
} 


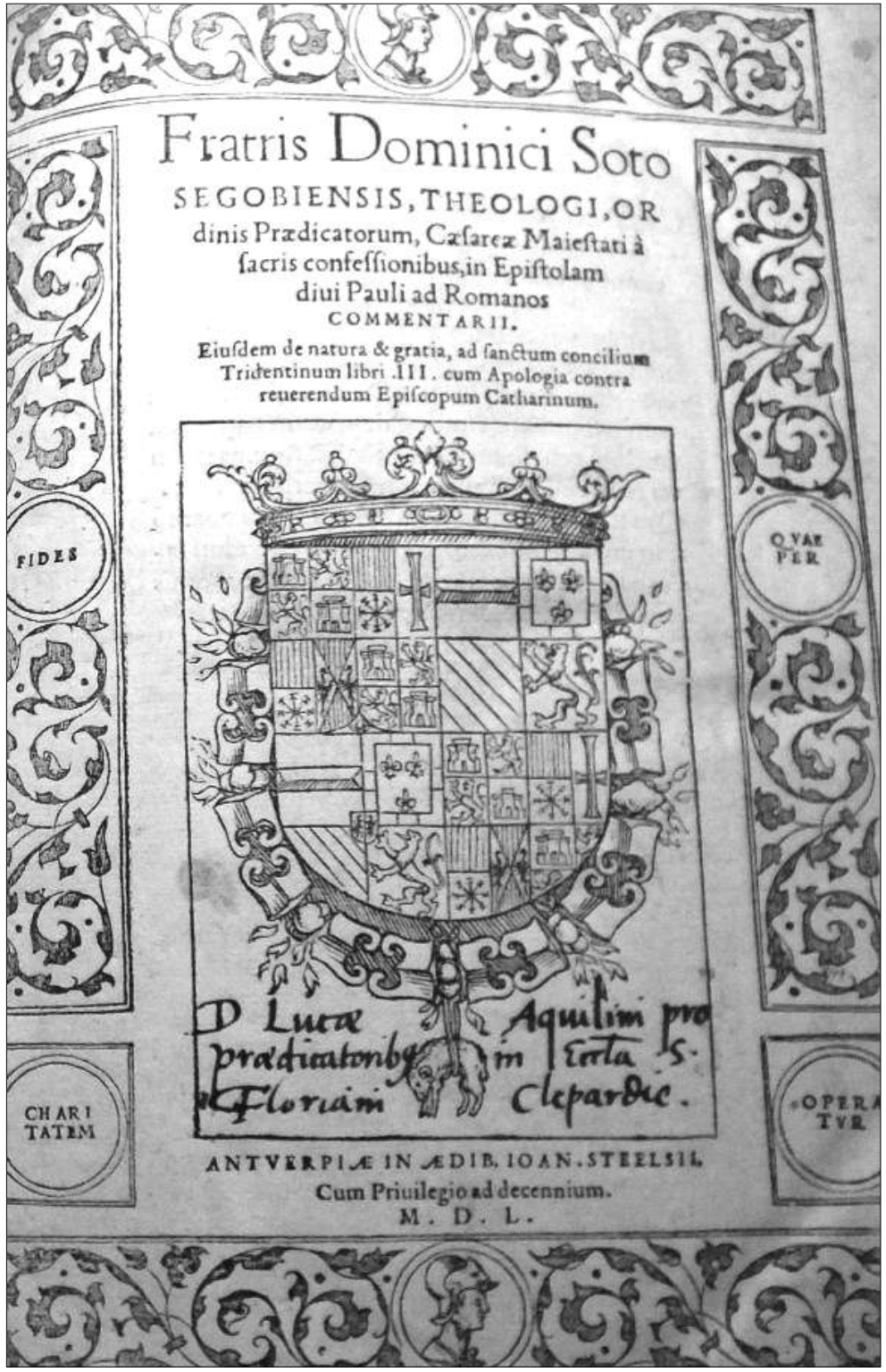

Dominicus Soto, In Epistolam divi Pauli..., z wpisem ,[...] in Ecclesia S. Floriani Clepardiae" 


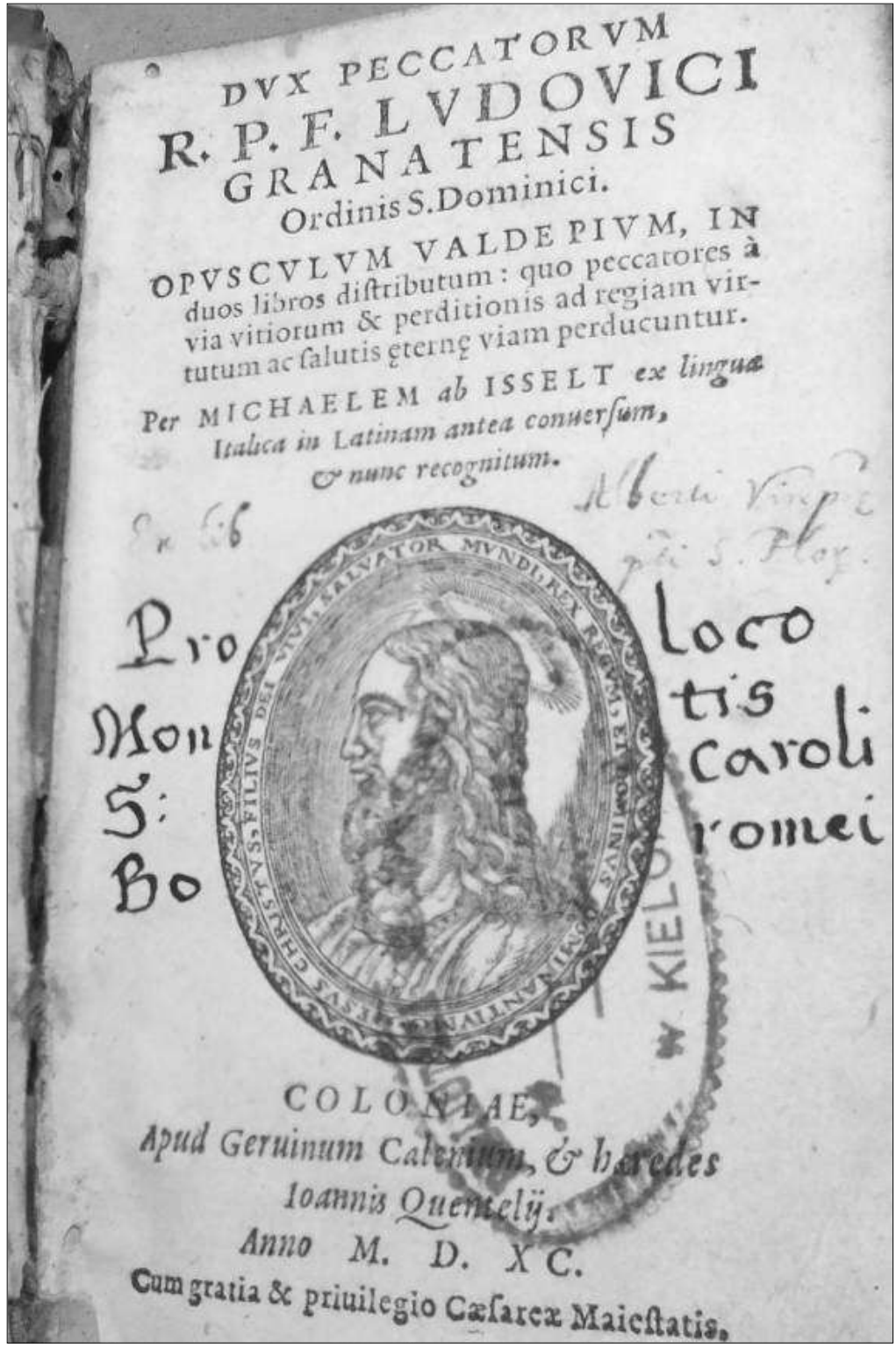

Ludovicus Grantensis, Dux Peccatorum, wpis proweniencyjny:

„Ex libris Alberti Vicepraepostiti S. Floriani;

Pro loco Montis S. Caroli Boromaei" 
Przeważnie darowizny kanoników kolegiaty św. Floriana na Kleparzu noszą znamiona dużego ciężaru jakościowego i historycznego, gdyż prebendy tej instytucji Kościoła dzierżyli profesorowie Uniwersytetu Krakowskiego ${ }^{49}$, zatem darowane przez nich księgi nie mogły być przypadkowe. Przypomnijmy, że są to tej miary dzieła i autorzy, jak: Regale Sacerdotium Petra Besseo, Cautela confessarii Augustino Matthaeucciego, In Epistolam divi Pauli ad Romanos commentarii Dominika Soto, Dux Peccatorum Ludwika z Granady.

Jeszcze ciekawszą darowizną, zarówno ze względu na objętość jak i zachowane oprawy, jest sześciotomowe wydanie rzadkiego w Polsce dzieła kartuza Wawrzyńca Suriusa o żywotach świętych. Darczyńcą był kolejny kanonik krakowski i kielecki - Marcin Rawa-Gawroński „Conventus S[ancti] Caroli. Ex libris Martini Rawa Gawronski Can[onici] Cr[acoviensis]"50, który poza wpisem proweniencyjnym upamiętnił się jeszcze wytłoczoną na okładzinach dolnych uproszczoną wersją herbu Rawicz (Rawa), mającą w zamyśle właściciela zapewne formę superekslibrisu ${ }^{51}$. Co prawda, udało się obecnie odnaleźć w zasobie BWSDK jedynie pięć tomów tego dzieła, ale $\mathrm{z}$ dużym prawdopodobieństwem graniczącym nawet $\mathrm{Z}$ pewnością, możemy założyć, że pierwotnie był to komplet. Co ważne, to rzadkie dzieło zachowało się także w bibliotece krakowskich bernardynów, co potwierdza ogromne znaczenie tego autora oraz jego dzieła dla Braci Mniejszych Obserwantów już w epoce nowożytnej ${ }^{52}$.

Podsumowując dotychczasowy stan badań nad księgozbiorem bernardynów z Karczówki, możemy stwierdzić, że w dużej mierze jego najstarsza część, a także najważniejsza pod względem treści i autorów niezbędnych dla formacji intelektualnej Braci Mniejszych Obserwantów, pochodziła z klasztoru macierzystego w Krakowie.

${ }^{49}$ B. K u m o r, Dzieje diecezji, s. 379-381.

${ }^{50}$ Laurentius S u r i u s, De Probatis Sanctorum Historiis..., t. 1-4, 6, Coloniae Agrippinae 1576-81, tamże, Katalog C 39-41, BS 106-107.

${ }^{51}$ Marcin Rawa Gawroński z Gawron h. Rawicz/Rawa, ok. 1582-1653, ojciec Andrzej Dawid, matka z Szyszkowskich, kanonik krakowski, K. N i e s i e c k i, Herbarz Polski, wyd. J. N. B o b r o w i c z, t. 4, Lipsk 1839-1845, s. 82-84; O jego działalności fundacyjnej na terenie Kielc, zob.: M. P i e n i ą ż e k - S a m e k, Tributum Gratitudinis Reddo. Fundacje artystyczne na terenie Kielc w XVII i XVIII wieku. Studium z historii literatury, Kielce 2005, s. 105, 296.

${ }^{52}$ W. S z e l i ń s k a, Krakowski katalog darczyńców zakonu bernardynów z lat 14531602, „Z Badań nad Polskimi Księgozbiorami Historycznymi”, t. spec., 1993, s. 113. 

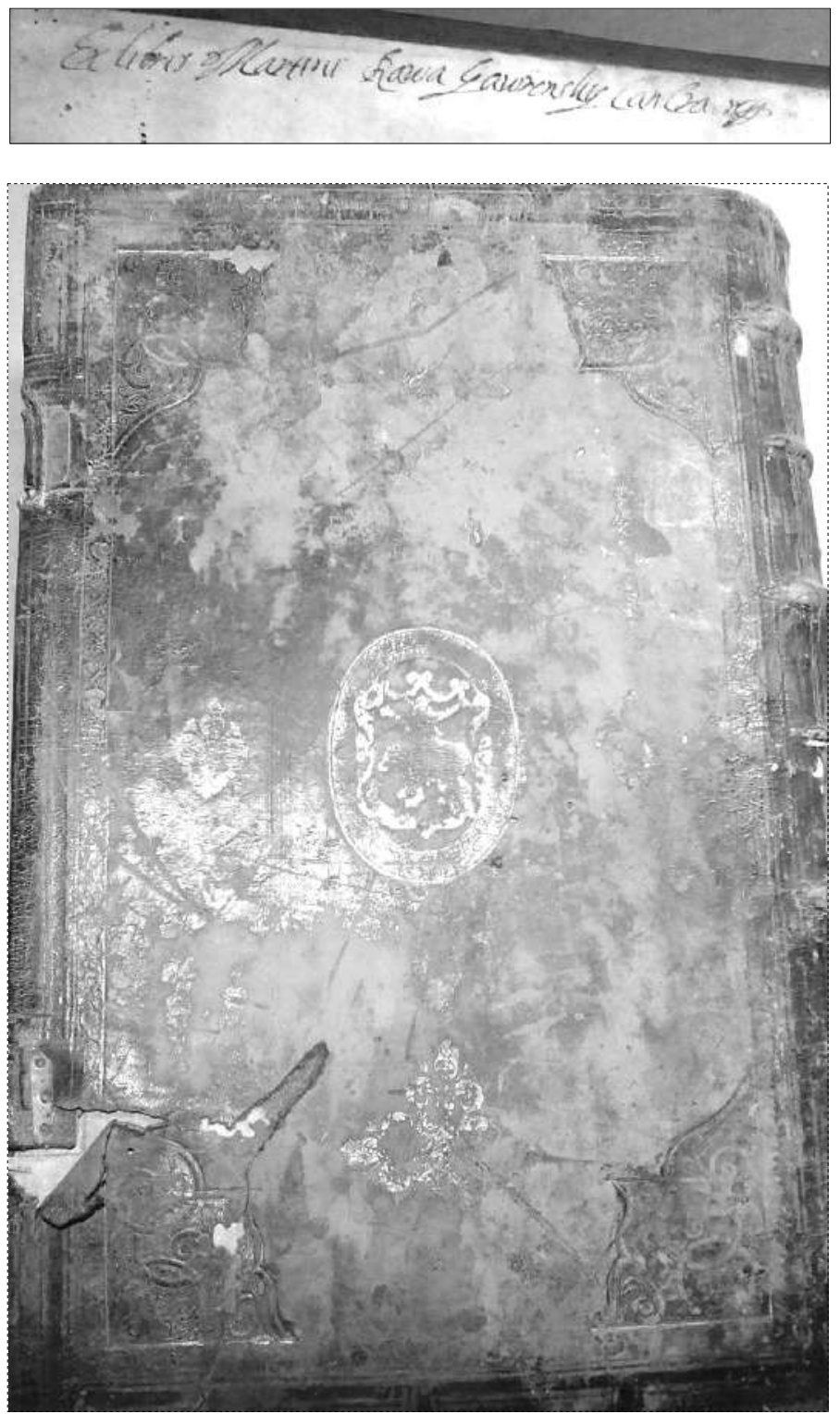

Laurentius Surius, De Probatis Sanctorum, t. 2, wpis proweniencyjny kanonika krakowskiego Marcina Rawy Gawrońskiego na wyklejce okładziny górnej i tłoczony herb na okładzinie dolnej 
Zauważalny jest bowiem związek tytułów z potrzebami tworzącej się wspólnoty zakonnej i jej zadaniami duszpasterskimi. Świadczy o tym co najmniej 31 woluminów. Władze zakonne prowincji oraz sympatyzujący z bernardynami kanonicy krakowscy oraz profesorowie tamtejszego uniwersytetu przekazywali Karczówce liczne starodruki, co po raz kolejny potwierdza popularność tego zakonu podczas odnowy trydenckiej $^{53}$. Odrębną grupę woluminów stanowią księgi, które $\mathrm{z}$ treści wpisów proweniencyjnych możemy przypisać bp. Marcinowi Szyszkowskiemu i jego bratankowi bp. Mikołajowi Szyszkowskiemu. Wątpliwości, co do przekazania fundacji na Karczówce bernardynom jeszcze za życia biskupa mają sami bernardyni, co stawia pod znakiem zapytania rzekomą darowiznę tychże ksiąg i bezpośrednie relacje fundatora kościoła pw. św. Karola Boromeusza. Uważam jednak, że mimo to, w tym konkretnym przypadku krakowskie ,pochodzenie" tychże woluminów jest pewne (np. mogły trafić na Karczówkę przy okazji fundacji kościoła).

Powyższe przykłady mogą stanowić interesujące uzupełnienie dotychczasowej wiedzy na temat sposobów powstawania księgozbiorów prowincjonalnych $\mathrm{w}$ niewielkich domach zakonnych $\mathrm{w}$ okresie staropolskim.

${ }^{53}$ Zob. cały szereg przykładów w artykule W. F. M u r a w c a, Księgozbiory, s. 50-51 i W. S z e li ń s k i e j, Krakowski katalog, s. 211-217. Już od XVI w. znane były tego typu przykłady, które wpisywały się w historię bernardynów krakowskich. Np. Jan Leopolita, doktor teologii, kaznodzieja katedralny i profesor uniwersytecki, legował swój księgozbiór klasztorowi krakowskiemu. Ich część ojciec szafarz przekazał klasztorowi bernardynów w Kościanie. Z kolei kustosz od św. Idziego, Tomasz Grodzisko, podarował swoje książki bernardynom krakowskim, przeworskim, lubelskim i kościańskim. Możliwe, że jest to wskazówka, w jaki sposób księgi po kanonikach krakowskich mogły zawędrować na Karczówkę. 


\section{BIBLIOGRAFIA}

\section{Źródla rękopiśmienne}

Rkps sygn. M-25, Chronologia ordinis Fratrum Minorum de Observantia Provinciae Minoris Polonia, Archiwum Prowincji oo. Bernardynów w Krakowie. Rkps sygn. 11802 (dawna: Ed XVII/2469), Anagryphe seu compendiosa descriptio Provinciae Poloniae Fratrum Minorum Observantium tam administrationis officia quam acta regiminis eiusdem provinciae concernentia complectens. Authoritate et mandato Superiorum hoc compendioso expressa stylo Anno Domini 1651, Muzeum Narodowe w Krakowie, Biblioteka Książąt Czartoryskich.

\section{Opracowania}

Biblioteki Kościoła katolickiego w Polsce. Informator, oprac. W. Żurek, Kielce 2005.

Biedrzycka A., Kawecki R., Szyszkowski Marcin, [w:] Polski Słownik Biograficzny, t. 50, Warszawa-Kraków 2014-2015, z. 206, s. 392-406.

Chwalewik E., Zbiory polskie, archiwa, biblioteki, gabinety, galerie, muzea i inne zbiory pamiątek przeszłości w ojczyźnie i na obczyźnie w porzadku alfabetycznym wedtug miejscowości ułożone, t. 1, Warszawa-Kraków 1926-1927.

Damirski C. OFM, Kronika bernardynów w Polsce (1453-1651), przekł. o. K. Żuchowski, Kalwaria Zebrzydowska 2016.

Dzieje Karczówki w Kielcach w latach 1624-2024, t. 1: Początki fundacji, insygnia, fundator, red. J. Michta, Kielce 2016.

Golichowski N., Przed nowa epoka. Materiaty do historii oo. Bernardynów w Polsce, Kraków 1899.

Jastrzębski C., Kasata klasztoru Bernardynów na Karczówce w 1864 roku, „Studia Muzealno-Historyczne” t. 4, 2012, s. 33-43.

Kantak K., Bernardyni polscy, t. 1-2, Lwów 1933.

Kantak K., Capitula nec non Constitutiones FF. Minorum Observantiam (Bernardinorum) Provinciae Poloniae 1453(1467)-1628, „Collectanea Theologica" 15,1934, nr 4, s. 459-462

Kantak K., Kapituły i Konstytucje bernardyńskie w XV i XVI w., „Przegląd Teologiczny" 10, 1929-1932.

Karczówka. Historia - literatura - architektura - przyroda, red. J. L. Olszewski, Kielce 1995.

Kardyś P., Patrum Bernardinorum Conventus Sancti Caroli Kielcijs ad Bibliothecam. Biblioteka oo. bernardynów z Karczówki od założenia konwentu do XIX wieku, [w:] Dzieje Karczówki w Kielcach (pod Kielcami) w latach 1624-2024, t. 6, Biblioteka bernardynów na Karczówce od 1632 roku do kasaty klasztoru w 1864 roku, red. J. Michta, Kielce 2019, s. 13-270. 
Kardyś P., Szyszkowiana/pseudoszyszkowiana z dawnego księgozbioru bernardynów z Karczówki przechowywane obecnie w zbiorach Biblioteki Wyższego Seminarium Duchownego w Kielcach, „Z Badań nad Książką i Księgozbiorami Historycznymi”, t. 12, 2018, s. 429-441.

Katalog rękopisów Biblioteki Seminarium Duchownego w Kielcach, „Archiwa Biblioteki i Muzea Kościelne” (dalej: ABMK) t. 40, 1980, s. 329-400; t. 41, 1980, s. 91-126.

Kowalski W., Biskup krakowski Marcin Szyszkowski a konsekwencje zarazy lat dwudziestych XVII stulecia, [w:] Człowiek i przyroda w średniowieczu $i$ we wczesnym okresie nowożytnym, red. W. Iwańczak i K. Bracha, Warszawa 2000, s. 227-244.

Kumor B., Dzieje diecezji krakowskiej do roku 1795, t. 2, Kraków 1999.

Lenart E., Biblioteki bernardyńskie w Polsce od 2. połowy XV wieku do końca wieku XVIII, [w:] Pięćset pięćdziesiąt lat obecności oo. Bernardynów $w$ Polsce (1453-2003), red. W. F. Murawiec, D. A. Muskus, Kalwaria Zebrzydowska 2006, s. 659-677.

Lenart E., Katalog bernardyńskich rękopisów liturgicznych $w$ Polsce od XV do XVIII wieku, ABMK 53, 1986, s. 103-274.

Łodyński M., Materiaty do dziejów państwowej polityki bibliotecznej w księstwie Warszawskim i Królestwie Polskim (1807-1831), Wrocław 1958.

Murawiec W. F., Kielce, [w:] Klasztory bernardyńskie w Polsce w jej granicach historycznych, red. H. E. Wyczawski, Kalwaria Zebrzydowska, 1985.

Murawiec W. F., Księgozbiory $i$ książki rękopiśmienne $w$ prawodawstwie ogólnym Zakonu Braci Mniejszych w późnym średniowieczu, „Folia Historica Cracoviensia" 6, 1999, s. 49-61.

Murawiec W. F., Księgozbiory krakowskie zakonu Braci Mniejszych - bernardynów i reformatów $-w$ świetle not proweniencyjnych $w$ XVI-XVIII $w$., „Folia Historica Cracoviensia” 2, 1994, s. 41-59.

Murawiec W. F., Poczatki biblioteki konwentu krakowskiego pw. św. Bernardyna ze Sieny, „Folia Historica Cracoviensia” 7, 2000, s. 93-111.

Niesiecki K., Herbarz Polski. wyd. J. N. Bobrowicz, t. 4, Lipsk 1839-1845, t. 8, Lipsk 1848.

Nir R., Informator o archiwach, bibliotekach i muzeach kościelnych $w$ Polsce, „Chrześcijanin w świecie” nr 56/57, 1977, s. 199-227.

Ozorowski E., Szyszkowski Marcin, [w:] Stownik Polskich Teologów Katolickich, t. 4, Warszawa 1983, s. 296-298.

Pieniążek-Samek M., Kościót i klasztor na Karczówce $w$ dobie nowożytnej; architektura i wyposażenie, „Studia Muzealno-Historyczne” t. 4, 2012, s. 11-31.

Pieniążek-Samek M., Tributum Gratitudinis Reddo. Fundacje artystyczne na terenie Kielc w XVII i XVIII wieku. Studium z historii literatury, Kielce 2005.

Prokop K. R., Poczet biskupów krakowskich, Kraków 1999. 
Stobiecka G., Pobernardyński zespół kościelno-klasztorny na Karczówce w Kielcach, „Rocznik Muzeum Świętokrzyskiego”, t. 8, 1973, s. 280-305. Szelińska W., Krakowski katalog darczyńców zakonu bernardynów z lat 1453-1602, „Z Badań nad Polskimi Księgozbiorami Historycznymi”, t. spec., 1993.

Ślaska K., Funkcja ksiązki w zakonie bernardynów w XVII w., „Z Badań nad Polskimi Księgozbiorami Historycznymi” 13, 1991, s. 131-151.

Tomczak S. B., Klasztory bernardyńskie w Polsce w jej granicach historycznych, [w:] Wkład bernardynów w życie religijno-kulturalne narodu polskiego (wybrane aspekty), red. Cz. Gniecki, A. K. Sitnik, Kalwaria Zebrzydowska 2016.

Wyczawski H. E., Bernardyni polscy, t. 3, 1772-1946, Kalwaria Zebrzydowska 1992.

Wyczawski H. E., Statuty zakonu Bernardynów w Polsce 1453-1795, „Prawo Kanoniczne" 25, 1982, z. 1-2, s. 179-196.

Wyczawski H. E., Zakon w Polsce, [w:] Klasztory bernardyńskie w Polsce w jej granicach historycznych, red. Tenże, Kalwaria Zebrzydowska 1985, s. 619-631.

Zbiory rękopisów $w$ bibliotekach i muzeach $w$ Polsce, oprac. D. Kamolowa przy współpr. K. Muszyńskiej (zbiory kościelne), Warszawa 1988.

Zdanowski J., Karczówka pod Kielcami, Kielce 1928.

\section{Wykaz fotografii}

Art. XIII i XIV dotyczące organizacji bibliotek i sposobów korzystania $\mathrm{z}$ księgozbiorów u bernardynów, fot. P. Kardyś. Anagryphe seu compendiosa..., BCzart., rkps 11802.

Dominicus Soto, In Epistolam divi Pauli..., z wpisem ,[...] in Ecclesia S. Floriani Clepardiae", fot. P. Kardyś.

Graduał bernardyński z Karczówki, XV w.(?)/pocz. XVI w., BWSDK Rl-6, fot. P. Kardyś.

Johannes Crombecius, De studio perfectionis..., wpis informujący o przeznaczeniu do refektarza na Karczówce w 1632 r., fot. P. Kardyś.

Laurentius Surius, De Probatis Sanctorum, t. 2, wpis proweniencyjny kanonika krakowskiego Marcina Rawy Gawrońskiego na wyklejce okładziny górnej i tłoczony herb na okładzinie dolnej, fot. P. Kardyś.

Ludovicus Grantensis, Dux Peccatorum, wpis proweniencyjny: „Ex libris Alberti Vicepraepostiti S. Floriani;

Początek inwentarza biblioteki bernardynów na Karczówce, fot. P. Kardyś. Archiwum Prowincji oo. Bernardynów w Krakowie, rkps M-25, s. 172 Pro loco Montis S. Caroli Boromaei”, fot. P. Kardyś.

Sermones Joannis Abbatis Vincellensis, z wpisem „Pro cella preadicatoris” konwentu św. Karola, fot. P. Kardyś. 
Woluminy z dawnej biblioteki bernardynów na Karczówce (obecnie BWSDK) z charakterystycznymi naklejkami inwentarzowymi, fot. P. Kardyś.

Wpis proweniencyjny przypisujący darowiznę woluminu dla konwentu na Karczówce bp. Marcinowi Szyszkowskiemu w 1630 r., fot. P. Kardyś. Bosquier Philippus, Codrus Evangelicus..., Katalog BS 17. 